\title{
miR-9 depletion suppresses the proliferation of osteosarcoma cells by targeting p16
}

\author{
SONG GAO, JIANCHAO WANG, SHUJIAN TIAN and JIANPING LUO \\ Department of Orthopedics, Henan Provincial People's Hospital, Zhengzhou, Henan 450003, P.R. China
}

Received September 12, 2018; Accepted April 2, 2019

DOI: $10.3892 /$ ijo.2019.4783

\begin{abstract}
Osteosarcoma (OS) is a common primary malignancy in adolescents and children. MicroRNAs (miRNAs or miRs) can regulate the progression of OS. Herein, we explored the target genes and effects of miR-9 in OS. Cell growth, colony formation and cell cycle were respectively examined using a cell counting kit-8 (CCK-8), crystal violet staining and flow cytometry. The target gene of miR-9 was predicted according to the MicroRNA.org website. Luciferase activity was examined using a dual luciferase reporter gene assay kit. The corresponding factors levels were analyzed by carrying out reverse transcription-quantitative PCR (RT-qPCR) and western blot analysis. A mouse model of OS was also established and the volume and weight of the tumors of the mice with OS were measured. The levels of p16 in the mice with OS were detected by immunohistochemistry (IHC). The data revealed a high expression of miR-9 and a low expression of p16 in the OS tissue. p16 was found to be the target gene for miR-9 in OS. miR-9 depletion decreased the proliferation and colony formation of Saos- 2 cells by arresting the cells at the G1 phase, accompanied by the downregulation of cyclin A, cyclin D1 and c-Myc expression levels. Moreover, miR-9 depletion inhibited the phosphorylation of p38, c-Jun N-terminal kinase (JNK) and extracellular signal-regulated kinase (ERK). In vivo, miR-9 depletion decreased the tumor volume and weight and increased p16 expression in the mouse tumor tissues. Nevertheless, p16 silencing reversed the suppressive effects of miR-9 inhibitors on OS cells. On the whole, the findings of this study substantiate that miR-9 depletion suppresses cell proliferation by targeting p16 in OS and by mediating the activation of the ERK/p38/JNK pathway.
\end{abstract}

Correspondence to: Dr Jianping Luo, Department of Orthopedics, Henan Provincial People's Hospital, 7 Weiwu Road, Zhengzhou, Henan 450003, P.R. China

E-mail: luojianping_jpluo@163.com

Key words: osteosarcoma, microRNA-9, proliferation, extracellular signal-regulated kinase/p38/c-Jun N-terminal kinase pathway

\section{Introduction}

Osteosarcoma (OS) is a common primary malignancy in adolescents and children, and it is associated with a high incidence rate, rapid progression and distant metastasis (1). The treatment of early OS is mainly surgical amputation. The 5-year survival rate of patients OS who only undergo amputation is approximately $16 \%$. However, this type of surgery is highly traumatic and is associated with a high disability rate (2). The application of neoadjuvant chemotherapy has significantly improved the 5-year survival rate of patients with OS; however, some patients are still insensitive to chemotherapy, and their treatment would also be affected by recurrence and metastasis of the tumor $(3,4)$. Although the occurrence of OS is relatively rare compared with other types of tumors, the basic research and clinical treatment strategies for OS have drawn much attention in the medical field, as it is associated with a high mortality and disability rate $(1,5)$. Therefore, it is important to identify effective and safe strategies with which to inhibit the progression of OS.

MicroRNAs (miRNAs or miRs) are a non-coding single chain RNA molecules of approximately 22 nucleotides in length, and they are widely distributed in plants, nematodes and human cells $(6,7)$. In 1993, scientists discovered miRNAs for the first time in Caenorhabditis elegans $(8,9)$. The number of miRNAs recognized in mammals has now reached tens of thousands. Researchers have found that miRNAs play a pivotal role in, for example, the biological processes of cell growth, differentiation, apoptosis and embryo development (10-13). The association between miRNAs and the occurrence and development of tumors has also attracted increasing attention in life science research (14). Researchers have found that miRNAs can regulate the progression of OS (15-17). miR-9 is a member of the miRNA family, and it has been found to be abnormally expressed in a number of types of tumor cells, such as breast cancer, lung cancer, gastric cancer and OS (18-22). Nevertheless, the specific role and targets of miR-9 in OS have not yet been fully elucidated.

Mitogen-activated protein kinases (MAPKs) are a class of intracellular threonine tyrosine protein kinases, and signal transduction is composed of cascade 3 cascade reactions $(23,24)$. Studies have confirmed that MAPKs exist in the majority of cells, and are associated with the proliferation, differentiation and apoptosis of various cells (25-27). Three different MAPK signaling pathways, 
including p38 MAPK, c-Jun N-terminal kinase (JNK) and extracellular signal-regulated kinase (ERK) $(28,29)$, have been found in mammals. A number of studies have confirmed that these 3 signals can regulate the progression of various types of tumors, for example, OS, prostate cancer and glioma (30-32).

In the present study, a target gene for miR-9 was predicted in OS according to the MicroRNA.org web site. We also examined the effects of miR-9 on the proliferation and cell cycle progression of human OS cells (Saos-2), and further analyzed the underlying molecular mechanisms.

\section{Materials and methods}

Tissue collection. From May, 2016 to June, 2017, 25 OS tissues and adjacent normal tissues were collected from patients with OS who were underwent treatment at Henan Provincial People's Hospital (Zhengzhou, China). All patients signed informed consent forms, allowing their tissues to be used in this study. The Ethics Committee of Henan Provincial People's Hospital authorized this research.

Cells and cell culture. Human OS cell lines (Saos-2) and 293 cells were obtained from JiningShiye (Shanghai, China). The cells were cultured in Dulbecco's modified Eagle's medium (DMEM; Solarbio, Beijing, China) containing $10 \%$ fetal bovine serum (FBS; MRC, Jiangsu, China) and 100X penicillin-streptomycin mixed solution (Leagene, Beijing, China) in an incubator at $37^{\circ} \mathrm{C}$ with $95 \%$ humidified and $5 \% \mathrm{CO}_{2}$ (SR80G, Sheyanyiqi, Shanghai, China).

Cell transfection and grouping. hsa-miR-9 mimics, hsa-miR-9 inhibitors and miRNA negative control (50 nM) were purchased from GenePharma (Shanghai, China). For p16 interference, siRNA p16 and unspecific scrambled siRNA (control siNC) were purchased from GenePharma. The sequences of selected regions to be targeted by siRNAs for p16 were as follows: 5'-TGC TGT TAG CTC TGC TCT TGG GAT TGG TTT TGG CCA CTG ACT GAC CAA TCC CAA GCA GAG CTAA-3' (sense), 5'-CCT GTT AGC TCT GCT TGG GAT TGG TCA GTC AGT GGC CAA AAC CAA TCC CAA GAG CAG AGC TAAC-3' (antisense). All transfections of the Saos-2 cells were conducted with the cells at 50-60\%

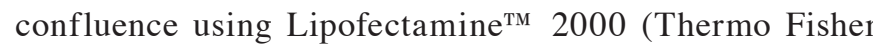
Scientific, Beijing, China) at $37^{\circ} \mathrm{C}$ for $48 \mathrm{~h}$.

This experiment established 10 different groups as follows: i) Negative control (Saos-2 cells were transfected with miRNA negative control); ii) hsa-miR-9 mimics (Saos-2 cells were transfected with hsa-miR-9 mimics); iii) hsa-miR-9 inhibitors (Saos-2 cells were transfected with hsa-miR-9 inhibitors); iv) control + p16-3'UTR (293 cells were transfected with miRNA negative control and p16-3'UTR); v) hsa-miR-9 + p16-3'UTR (293 cells were transfected with hsa-miR-9 mimics and p16-3'UTR); vi) hsa-miR-9 + p16-3'UTR-mut (293 cells were transfected with hsa-miR-9 mimics and p16-3'UTR-mutant); vii) si-p16 (Saos-2 cells were transfected with siRNA p16); viii) control + si-NC (Saos-2 cells were transfected with unspecific scrambled siRNA); ix) hsa-miR-9 inhibitors + si-NC (Saos-2 cells were transfected with hsa-miR-9 inhibitors and unspecific scrambled siRNA); and x) hsa-miR-9 inhibitors + si-p16 (Saos-2 cells were transfected with hsa-miR-9 inhibitors and siRNA p16). These cell groups were used in different assays as needed.

Luciferase reporter assay. The MicroRNA.org website (http://www.microrna.org/microrna/getMirnaForm.do) was used to predict the target gene of miR-9, and the dual luciferase reporter assay was used to confirm the findings. Luciferase activity was detected using the double luciferase report system detection kit (Promega Corp., Madison, WI, USA). Firstly, hsa-miR-9 mimics and miRNA negative control were co-transfected with p16-3'UTR or p16-3'UTR mutant plasmids (400 ng) into 293 cells using Lipofectamine ${ }^{\mathrm{TM}} 2000$ for $48 \mathrm{~h}$. The cells were then lysed using $1 \mathrm{X}$ passive lysis buffer (PLB) at $37^{\circ} \mathrm{C}$ for $15 \mathrm{~min}$. The cell suspension was transferred to a black enzyme plate. LARII and stop\&Glo ${ }^{\circledR}$ reagent (Promega Corp.) was then added to the plate in a drop-wise manner. Luciferase activity was measured using a GloMax ${ }^{\circledR}$ Discover Multimode Microplate Reader (GM3000; Promega Corp.). pRL-TK (Promega Corp.) was used as an internal control.

Reverse transcription-quantitative PCR (RT-qPCR). Total RNA was isolated from the cells and tissues using an RNA extraction kit (Takara, Beijing, China). cDNA was synthesized using a ABScript II cDNA First Strand Synthesis kit (ABclonal, Wuhan, China). The reaction conditions were set at $85^{\circ} \mathrm{C}$ for $15 \mathrm{~min}$. Subsequently, cDNA was amplified using the TeloPrime Full-Length cDNA Amplification kit (Lexogen, Beijing, China). qPCR experiments were performed using a SYBR Premix Ex Taq ${ }^{\mathrm{TM}}$ Real-Time PCR Kit (Takara Bio, Inc., Otsu, Japan). The reaction conditions were set at $90^{\circ} \mathrm{C}$ for $20 \mathrm{sec}$, (at $90^{\circ} \mathrm{C}$ for $10 \mathrm{sec}$ and at $58^{\circ} \mathrm{C}$ for $40 \mathrm{sec}$ ) for $35 \mathrm{cycles}$, at $72^{\circ} \mathrm{C}$ for $3 \mathrm{~min}$. The sequences of the primers used are listed in Table I. U6 and GAPDH were used as internal controls. Gene expression was quantified using the $2^{-\Delta \Delta \mathrm{Cq}}$ method (33).

Western blot analysis. Total protein was isolated from the cells and tissues were using RIPA buffer (Solarbio). The BCA protein assay (Thermo Fisher Scientific) was carried out to measure the contents of the proteins. Each protein $(10 \mu \mathrm{g})$ was separated by $12 \%$ sodium dodecyl sulfate-polyacrylamide gel electrophoresis (SDS-PAGE) and blotted onto a PVDF membrane (Reno, Hangzhou, China). Subsequently, the PVDF membrane was soaked in TBST-soluble 5\% dried skimmed milk at room temperature for $2 \mathrm{~h}$. The membrane was respectively bound to the corresponding primary antibodies [anti-p16, ab118459, 1:800; anti-ERK, ab224313, 1:700; anti-p-ERK, ab214036, 1:700; anti-JNK, ab208035, 1:1,000; anti-p-JNK, ab124956, 1:1,000; anti-GAPDH, ab181602, 1:800; all from Abcam (Cambridge, MA, USA); anti-cyclin A, sc-271682, 1:800; anti-cyclin D1 sc-246, 1:1,000; anti-c-Myc, sc-373712, 1:600; anti-p-38, sc-7972, 1:800; anti-p-p38 sc-7975-R, 1:800; all from Santa Cruz Biotechnology (Santa Cruz, CA, USA)] at $4^{\circ} \mathrm{C}$ for $24 \mathrm{~h}$. After binding, the PVDF membrane was bound to the corresponding secondary antibodies (goat anti-rabbit IgG H\&L, ab150077, 1:6,000; rabbit anti-mouse IgG H\&L, ab6726, 1:6,000; Abcam) at $37^{\circ} \mathrm{C}$ for $1 \mathrm{~min}$. The blots were assessed using ECL detection reagent (Yeasen, Shanghai, China), and densitometry was performed using the Bio-Rad ChemiDoc system with Image Lab software version 6.0 (Bio-Rad Laboratories, Inc., Hercules, CA, USA). 
Table I. The sequences of the primers used for RT-qPCR.

\begin{tabular}{llc}
\hline $\begin{array}{l}\text { Primer } \\
\text { name }\end{array}$ & \multicolumn{1}{c}{$\begin{array}{c}\text { Sequence } \\
\left(5^{\prime}-3^{\prime}\right)\end{array}$} & $\begin{array}{c}\text { Product } \\
\text { size (bp) }\end{array}$ \\
\hline miR-9 & $\begin{array}{l}\text { F: GTGCAGGGTCCGAGGT } \\
\text { R: GCGCTCTTTGGTATCTAGC }\end{array}$ & 206 \\
p16 & $\begin{array}{l}\text { F: CAGGTCATGATGATGGGCAG } \\
\text { R: GATGGCCCAGCTCCTCAG }\end{array}$ & 223 \\
& $\begin{array}{l}\text { F: TAACCAGGTGATCGTGCAGT } \\
\text { Cyclin D1 }\end{array}$ & F: CCCTCGGTGTCCTACTTCAA \\
& R: CTTAGAGGCCACGAACATGC & 219 \\
c-Myc & F: GGACGACGAGACCTTCATCA & \\
& R: CGTTGAGAGGGTAGGGGAAG & 245 \\
U6 & F: ACACCAAGCAGTCCGAAGAG & \\
& R: ACAAAATTCTCACGCCGGT & 220 \\
GAPDH & F: CCATCTTCCAGGAGCGAGAT & \\
& R: TGCTGATGATCTTGAGGCTG & 222 \\
\hline
\end{tabular}

F, forward; R, reverse.

Cell counting kit-8 (CCK-8) assay. The Saos-2 cells were seed in a 96 -well plate $\left(1.5 \times 10^{3}\right.$ cell/well $)$ in an incubator at $37^{\circ} \mathrm{C}$ for $24 \mathrm{~h}$. The cells were subjected to transfection with the corresponding plasmids for 0,12 and 24 and $48 \mathrm{~h}$. Subsequently, the cells were treated with CCK- 8 reagent at $37^{\circ} \mathrm{C}$ for $4 \mathrm{~h}$. The value of OD at $450 \mathrm{~nm}$ was read using a SpectraMax iD5 microplate reader (Molecular Devices, Shanghai, China).

Colony formation assay. The Saos- 2 cells were seeded in a $60-\mathrm{mm}$ culture dish $\left(2.5 \times 10^{4} \mathrm{cell} / \mathrm{ml}\right)$ in an incubator for $24 \mathrm{~h}$ at $37^{\circ} \mathrm{C}$. The cells were then exposed to miRNA negative control, hsa-miR-9 mimics and hsa-miR-9 inhibitors. After the cells have been transfected for $24 \mathrm{~h}$, the cells were fixed using polyoxymethylene at room temperature for $20 \mathrm{~min}$. The cells were then stained by $0.1 \%$ crystal violet (Solarbio) at room temperature for $30 \mathrm{~min}$.

Cell cycle assay. The Saos- 2 cells were seeded in a 6-well plate $\left(3 \times 10^{4}\right.$ cell/well $)$ in an incubator at $37^{\circ} \mathrm{C}$ for $24 \mathrm{~h}$. The cells were then exposed to the corresponding plasmids for $48 \mathrm{~h}$. The cells were then fixed by paraformaldehyde for $25 \mathrm{~min}$ at $4^{\circ} \mathrm{C}$. The cells were subsequently stained with propidium iodide (PI; Leagene, Beijing, China) for $30 \mathrm{~min}$ at room temperature. At least $4 \times 10^{3}$ cells were collected for assay using a FACScan flow cytometer (BD Biosciences, San Jose, CA, USA).

Establishment of mouse model of OS. All animal experiments were performed following the approval of the Henan Provincial People's Hospital Animal Ethics Committee and according to the Guidelines for the Care and Use of Laboratory Animals. A total of $6 \mathrm{Balb} / \mathrm{c}$ nude mice per group (6-8 weeks old; weighing $20 \pm 2$ g) were provided by Rochen (Shanghai, China). Following transfection, the Saos- 2 cells suspension $\left(10^{6}\right.$ cells per mouse $)$ was injected into the subcutaneous tissue of the nude mice to produce OS tumor xenografts.

Tumor volume and weight assay. After 15, 20, 25, 30, 35, 40 and 45 days of culture, the length and width of the tumors in each group of animals (6 in each group; 3 groups) were counted using the caliper, tumor volume $=\left(\right.$ width $^{2} \mathrm{x}$ length $) / 2$, as previously described (34). The animals were sacrificed after 45 days. Tumor mass was calculated. The tumor weights were detected using an electronic balance (SECURA213-1CN; Sartorius, Goettingen, Germany).

Immunohistochemistry (IHC). The animals were sacrificed and tumors were collected. The samples were dehydrated in a graded ethanol followed by routine paraffin embedding and sectioning. The paraffin-embedded tissue slices were then washed with distilled water 3 times. The slices were soaked in a citrate buffer ( $\mathrm{pH} \mathrm{6.0)}$ at room temperature for $30 \mathrm{~min}$. The hydrogen peroxide reagent was then dripped into the slices at room temperature for $10 \mathrm{~min}$. Subsequently, the slices were sealed using goat serum at room temperature for $20 \mathrm{~min}$. The anti-p16 antibody (ab151303, 1:800) was added to the slices at $4^{\circ} \mathrm{C}$ for $24 \mathrm{~h}$. The following day, the secondary antibodies (goat anti-rabbit IgG-HRP; ab205718, 1:2,000) (both from Abcam) were dripped onto the slices at room temperature for $20 \mathrm{~min}$. The slices were then stained by DAB staining solution (Leica, Shanghai, China) at room temperature for $15 \mathrm{~min}$. The slices were then cleaned with distilled water for 3 times. Subsequently, the slices were dyed using hematoxylin (Solarbio) for $3 \mathrm{~min}$ at room temperature. The slices were observed under a fluorescence microscope (MF43; Mshot, Guangzhou, China).

Statistical analysis. The data are presented as the means \pm standard deviation (SD) and were analyzed using IBM SPSS 20 statistical software. The Student's t-test was used to analyze differences between 2 groups and differences between the paired patient tissues. The differences among groups were analyzed by one-way analysis of variance (ANOVA) followed by Dunnett's t-test. The Chi-square test was carried out to examine the association between p16 expression and the clinicopathological characteristics of the patients with OS. Pearson's correlation test (2-tailed) was applied to analyze the correlation between p16 and miR-9 expression. A value of $\mathrm{P}<0.05$ was considered to indicate a statistically significant difference.

\section{Results}

miR-9 is expressed at high levels and pl6 is expressed at low levels in patients with $O S$. In order to examine the expression of miR-9 and p16 in normal tissue and OS tissue, western blot analysis and RT-qPCR were performed. As shown by the RT-qPCR data, the mRNA level of miR-9 in the OS tissue was higher than that in the normal tissue; however, the mRNA level of p16 in the OS tissue was lower than that in the normal tissue (Fig. 1A and B). In addition, the western blot analysis results revealed that compared to the normal tissue, the p16 protein level was decreased in the OS tissue (Fig. 1C). A negative correlation between the expression of miR-9 and p16 


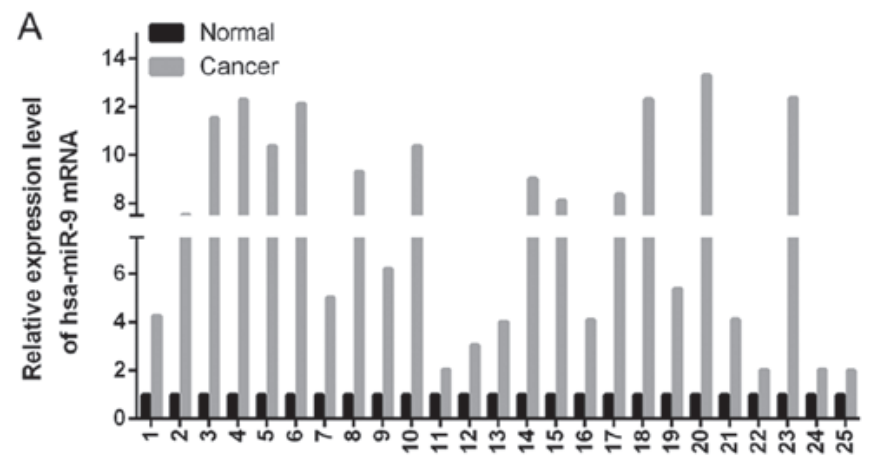

C

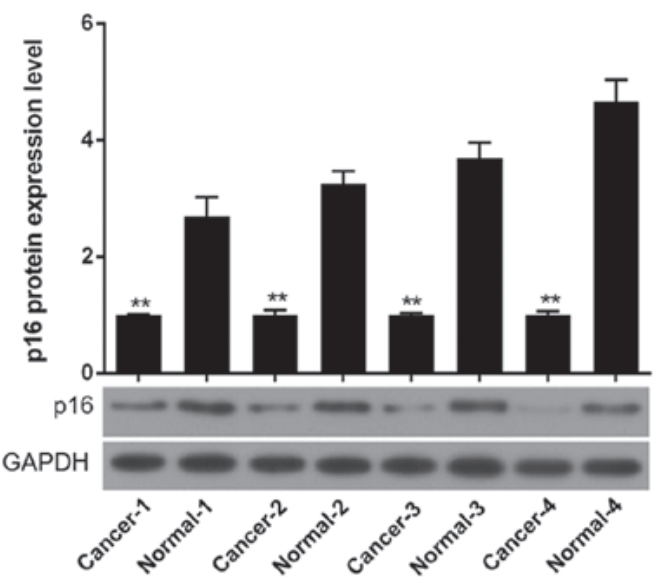

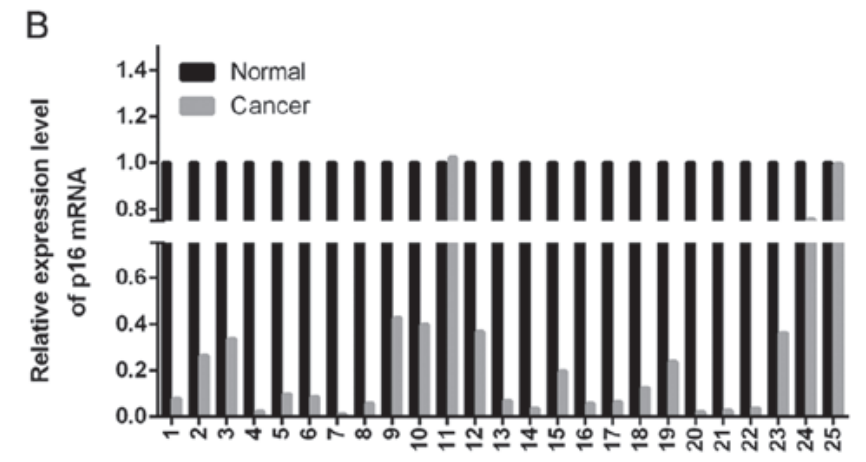

D

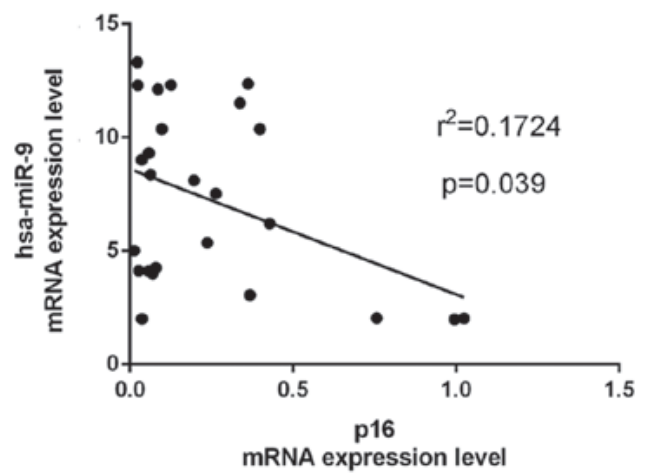

Figure 1. miR-9 is highly expressed and p16 was expressed at low levels in patients with OS. (A and B) The mRNA levels of miR-9 and p16 in OS tissue and adjacent normal tissue were analyzed by RT-qPCR. (C) Western blot analysis was applied to detect p16 expression. (D) The correlation between the mRNA levels of miR-9 and p16 in OS was determined. ${ }^{* *} \mathrm{P}<0.01$ vs. normal tissue. OS, osteosarcoma.

Table II. Association between p16 expression and the clinicopathological characteristics of patients with osteosarcoma.

\begin{tabular}{lcccc}
\hline & $\begin{array}{c}\text { No. of } \\
\text { Groups }\end{array}$ & Low p16 & High p16 & \\
patients & expression & expression & P-value
\end{tabular}

Age (years)

$\begin{array}{lllll}<60 & 15 & 8 & 7 & 0.513 \\ \geq 60 & 10 & 4 & 6 & \end{array}$

Sex

$\begin{array}{llll}\text { Male } & 12 & 5 & 7 \\ \text { Female } & 13 & 6 & 7\end{array}$

Tumor size $(\mathrm{cm})$

$<3$

$\geq 3$

9

2

12

$0.025^{\mathrm{a}}$

TNM stage

$\begin{array}{lrrr}\text { I and II } & 8 & 3 & 5 \\ \text { III and IV } & 17 & 14 & 3\end{array}$

Lung metastasis

\begin{tabular}{lrrr} 
No & 14 & 4 & 10 \\
Yes & 11 & 9 & 2 \\
\hline
\end{tabular}

${ }^{a} \mathrm{P}<0.05$ and ${ }^{\mathrm{b}} \mathrm{P}<0.01$, indicate statistical significance, determined by the Chi-square test.

$0.008^{\mathrm{b}}$ in 4 randomly selected pairs of OS patient tissue (Fig. 1D) was also observed. The clinicopathological data demonstrated that rather than age or sex, a low expression of p16 in patients with OS was associated with tumor size, TNM stage and lung metastasis (Table II).

miR-9 depletion suppresses the proliferation of Saos-2 cells. The results of RT-qPCR revealed that the miR-9 mRNA level was increased in the cells exposed to hsa-miR-9 mimics, while the mRNA levels of miR-9 were decreased in the cells transfected with hsa-miR-9 inhibitors (Fig. 2A and D). As shown by the results of CCK-8 assay, the value of OD at $450 \mathrm{~nm}$ was enhanced in the cells transfected with hsa-miR-9 mimics (Fig. 2B); however, it was decreased in the cells transfected with hsa-miR-9 inhibitors (Fig. 2E). The colony formation assay results indicated that the relative colony number was increased in the cells transfected with hsa-miR-9 mimics (Fig. 2C), whereas it was decreased in the cells transfected with hsa-miR-9 inhibitors (Fig. 2F).

miR-9 depletion arrests the cell cycle at the G1 phase by downregulating cyclin A, cyclin DI and c-Myc expression in Saos-2 cells. The cell cycle analysis data revealed that the number of $\mathrm{S}$ phase cells was high in the hsa-miR-9 mimics group, whereas the number of cells in the G1 phase was elevated in the hsa-miR-9 inhibitors group. However, the number of cells in the G2 phase in the hsa-miR-9 mimics and 

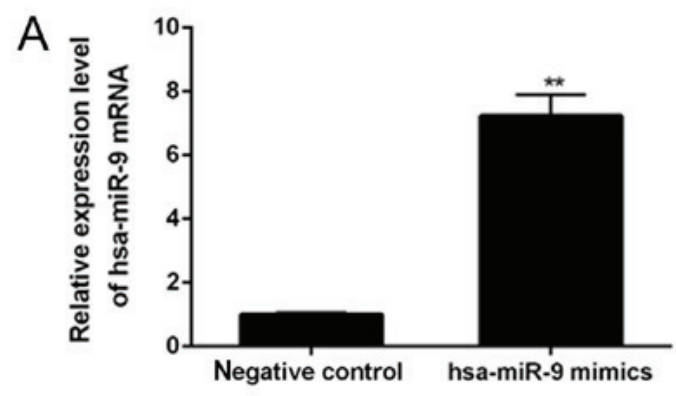

B

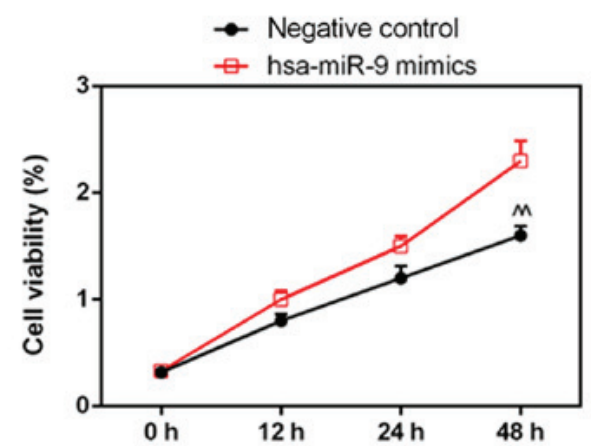

C
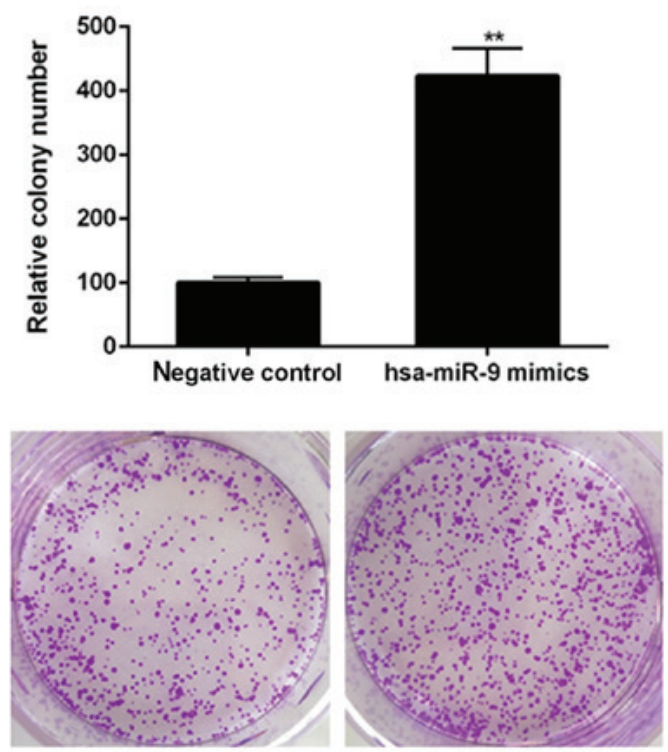

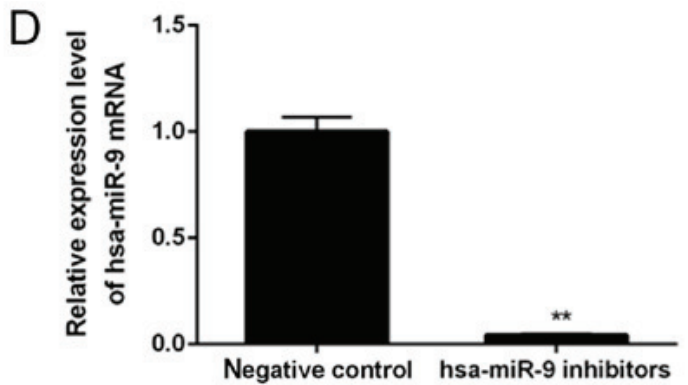

E

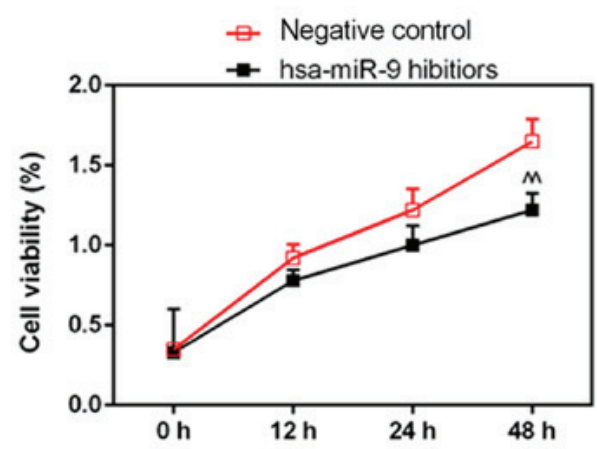

$\mathrm{F}$
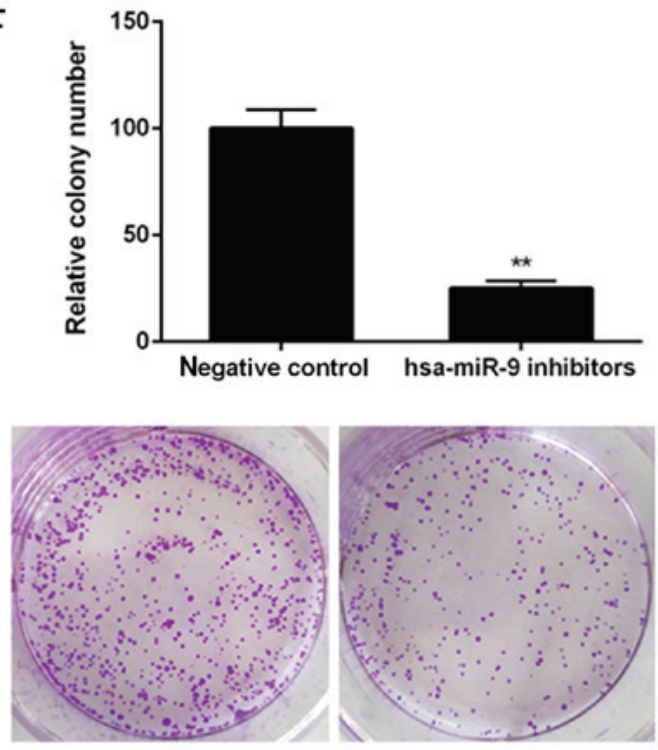

Figure 2. miR-9 depletion decreases the proliferation of Saos-2 cells. Saos-2 cells were subjected to transfection with hsa-miR-9 mimics, hsa-miR-9 inhibitors and miRNA negative control. (A) hsa-miR-9 mRNA expression was detected by RT-qPCR in cells transfected with hsa-miR-9 mimics. (B) The OD value at $450 \mathrm{~nm}$ was read by CCK-8 assay in cells transfected with hsa-miR-9 mimics. (C) Colony formation was analyzed by crystal violet staining in cells transfected with hsa-miR-9 mimics. (D) hsa-miR-9 mRNA expression was detected by RT-qPCR in cells transfected with hsa-miR-9 inhibitors. (E) The OD value at $450 \mathrm{~nm}$ was read by CCK- 8 assay in cells transfected with hsa-miR-9 inhibitors. (F) Colony formation was analyzed by crystal violet staining in cells transfected with hsa-miR-9 inhibitors. ${ }^{* *} \mathrm{P}<0.01$ vs. negative control.

hsa-miR-9 inhibitors group decreased (Fig. 3A). In addition, the protein and mRNA levels of cyclin A, cyclin D1 and c-Myc were upregulated in the hsa-miR-9 mimics, but downregulated in the hsa-miR-9 inhibitors group (Fig. 3B and C).

miR-9 depletion increases p16 expression in Saos-2 cells. According to the microRNA.org website, p16 was a target gene for miR-9. By performing luciferase assay, we then found that the luciferase activity was suppressed in the cells transfected with hsa-miR-9 mimics and p16-3'UTR; however, it remained stable in the hsa-miR-9 + p16-3'UTR mut group cells (Fig. 4A). The mRNA and protein expression levels of p16 were also found to be elevated when the cells were transfected with hsa-miR-9 inhibitors. However, when the cells were transfected with hsa-miR-9 mimics, the mRNA and protein levels of p16 were suppressed (Fig. 4B and C).

Silencing of p16 enhances the proliferation of Saos-2 cells by promoting cell cycle G1 phase to S phase transformation. As shown by the results of RT-qPCR and western blot analysis, the mRNA and protein levels of p16 were decreased in the cells transfected with siRNA p16, compared to the negative control (Fig. 5A and B). The CCK-8 data also revealed that the OD value was elevated in the cells transfected with siRNA 
A

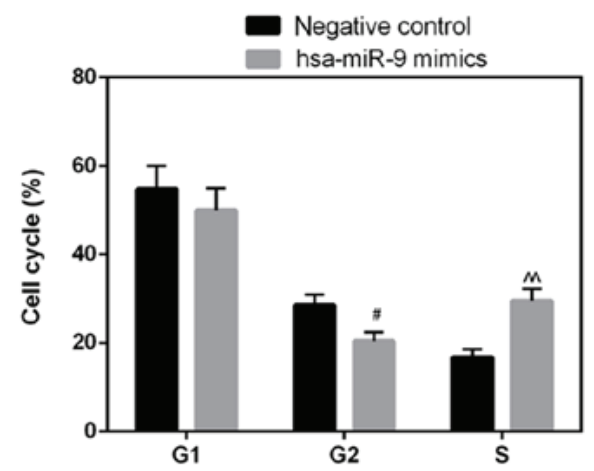

B
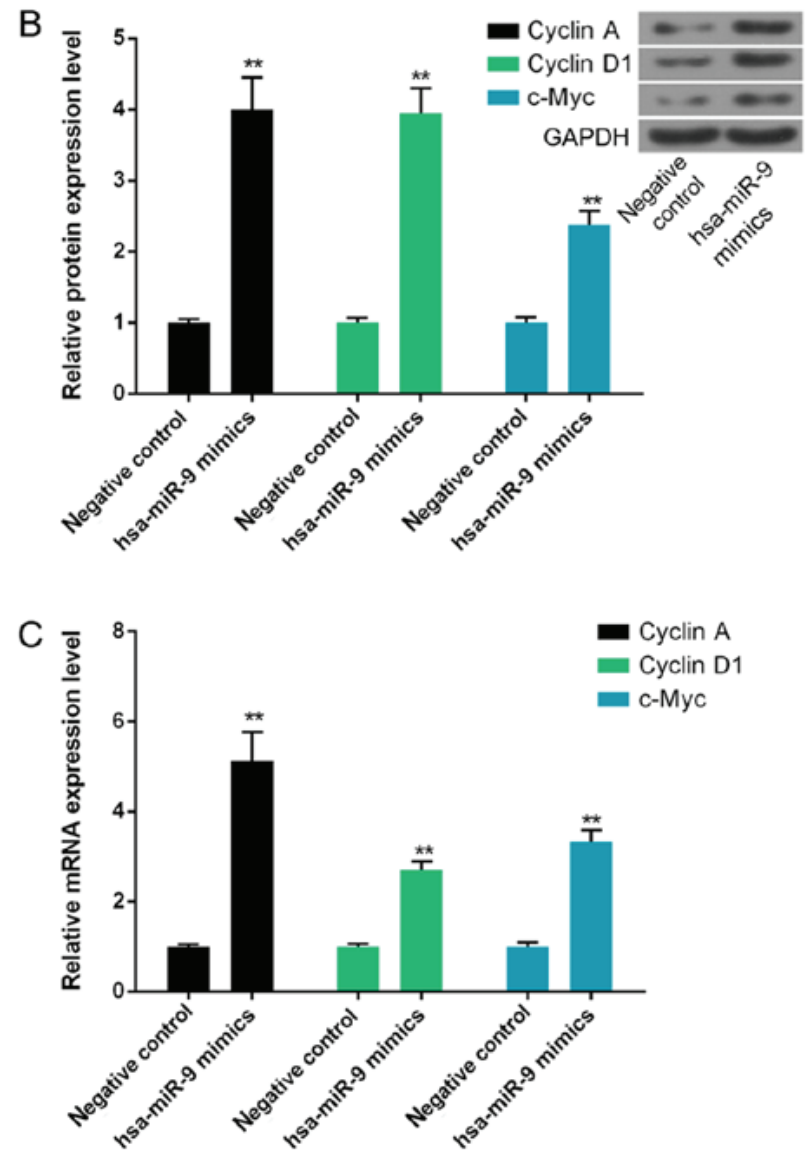
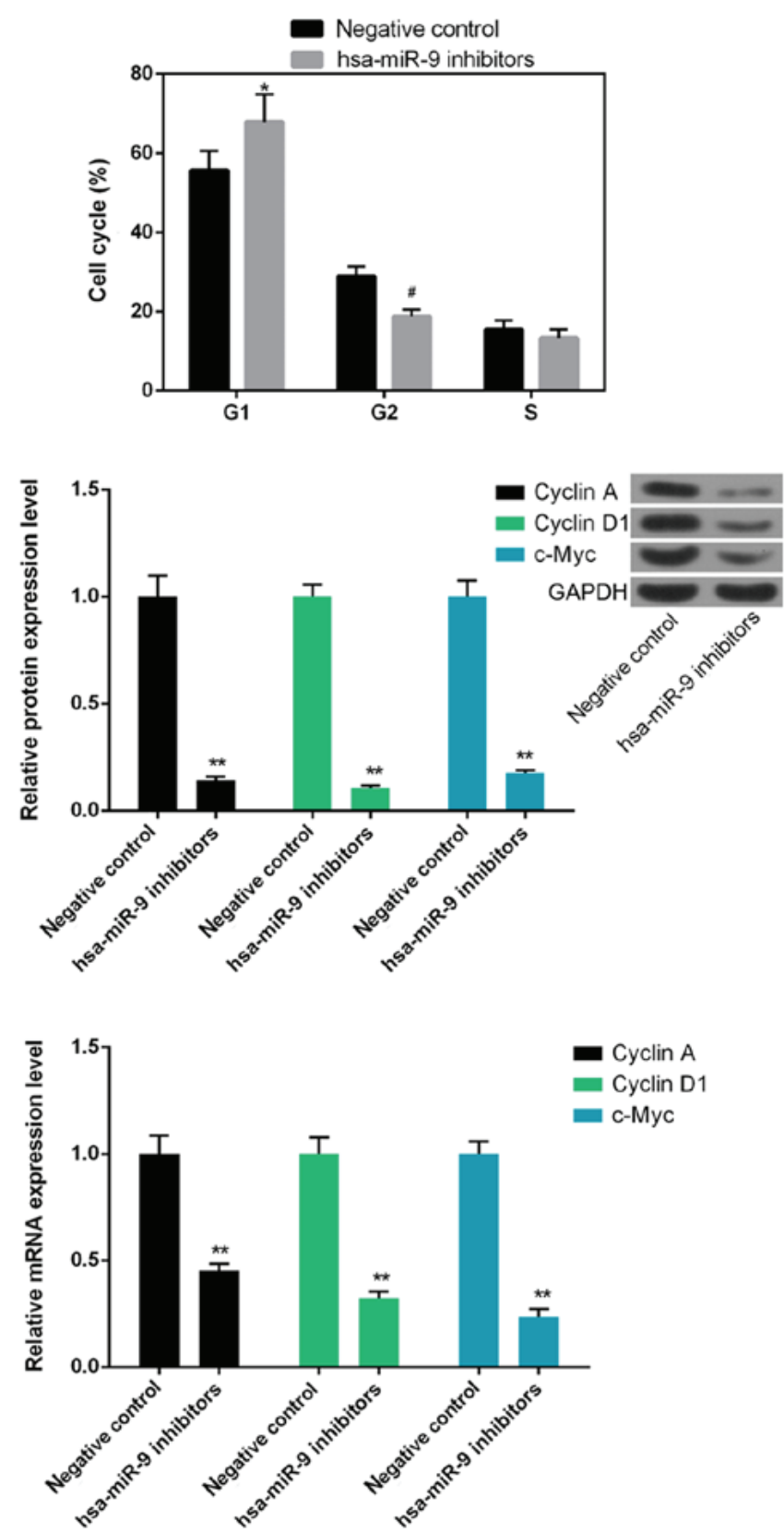

Figure 3. miR-9 depletion arrests the cells at the G1 phase by downregulating cyclin A, cyclin D1 and c-Myc expression in Saos-2 cells. (A) Cell cycle was examined by flow cytometry. (B and C) Western blot analysis and RT-qPCR were performed to assess cyclin A, cyclin D1 and c-Myc expression levels. ${ }^{*} \mathrm{P}<0.05$ and ${ }^{* *} \mathrm{P}<0.01$ vs. negative control; ${ }^{*} \mathrm{P}<0.05$ and ${ }^{\wedge \wedge} \mathrm{P}<0.01$ vs. negative control.

p16 (Fig. 5C). The depletion of p16 significantly increased the number of cells in the $\mathrm{S}$ phase, while it reduced the number of cells in the G1 phase (Fig. 5D).

Silencing of p16 reverses the inhibitory effects of miR-9 inhibitor on Saos-2 cell proliferation by promoting cell cycle $G 1$ phase to $S$ phase transformation. The results of qRT-qPCR and western blot analysis revealed that the mRNA and protein levels of p16 were markedly decreased in the hsa-miR-9 inhibitors + si-p16, compared to the hsa-miR-9 inhibitors + si-NC group (Fig. 6A and B). When the cells were transfected with has-miR-9 inhibitors and siRNA p16, the OD value was elevated (Fig. 6C), and the number of cells in the G1 phase decreased, and the number of cells in the G2 phase increased (P<0.05; Fig. 6D).
Silencing of p16 reverses the inhibitory effects of miR-9 inhibitor on the activation of the ERK/p38/JNK pathway in Saos-2 cells. To examine the effects of miR-9 inhibitor and siRNA p16 on the ERK/p38/JNK pathway in Saos-2 cells, western blot analysis was performed. The results revealed that miR-9 inhibitor suppressed the phosphorylation of ERK, p38 and JNK. Nevertheless, the expression levels of total ERK, p38 and JNK remained stable. The proportions of p-ERK/ERK, p-p38/p38 and p-JNK/JNK were markedly reduced in the hsa-miR-9 inhibitors + si-NC group. However, in comparison with the hsa-miR-9 inhibitors + si-NC group, the phosphorylation levels of ERK, p38 and JNK were elevated in the hsa-miR-9 inhibitors + si-p16 group. The proportions of p-ERK/ERK, p-p38/p38 and p-JNK/JNK were also increased in the hsa-miR-9 inhibitors + si-p16 group (Fig. 7). 

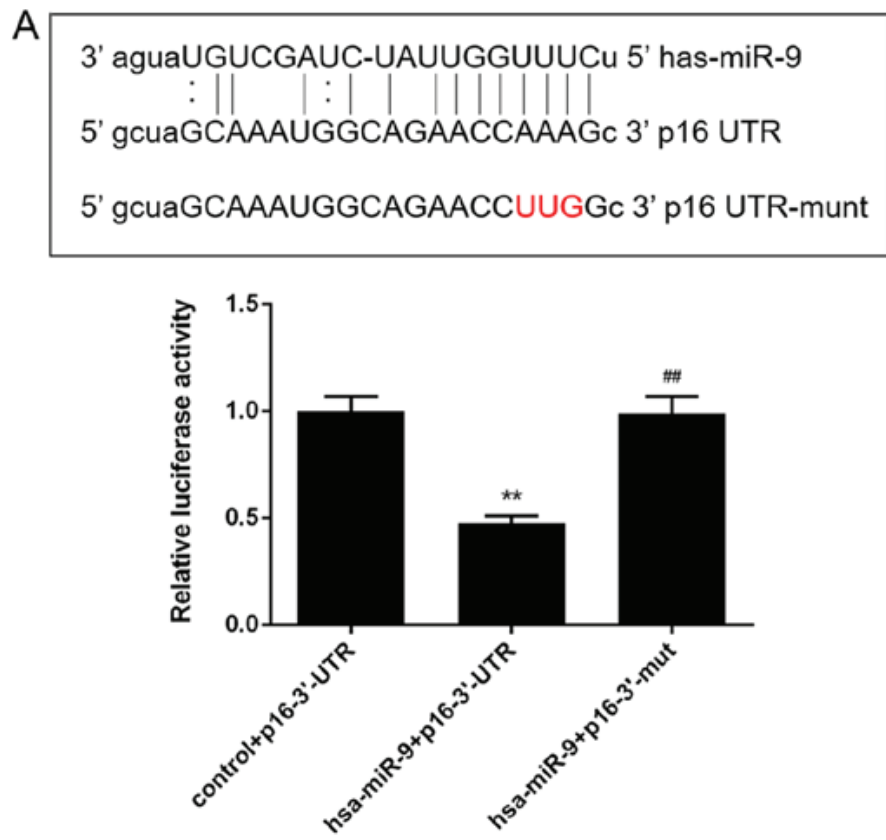

C

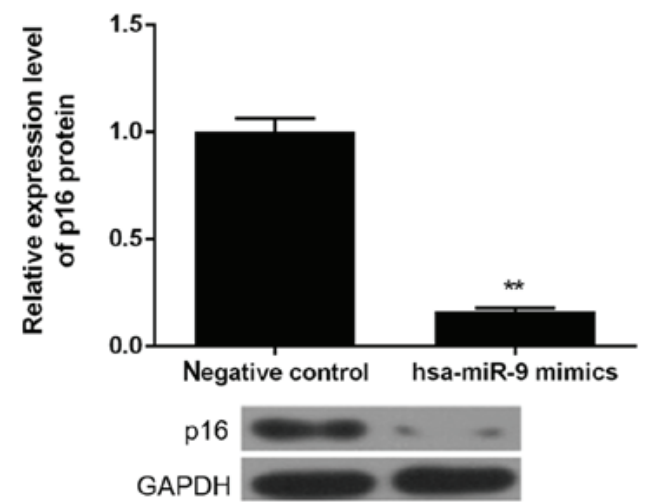

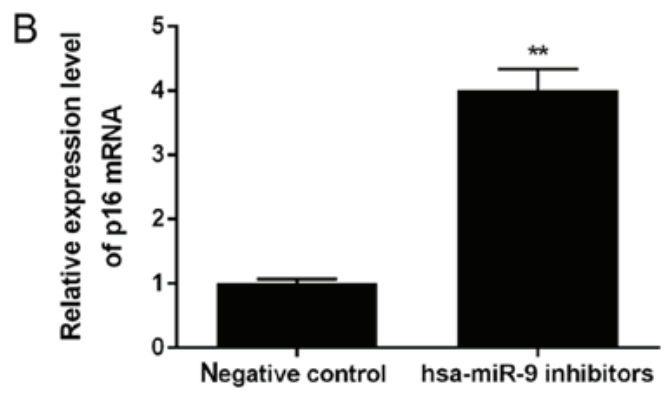
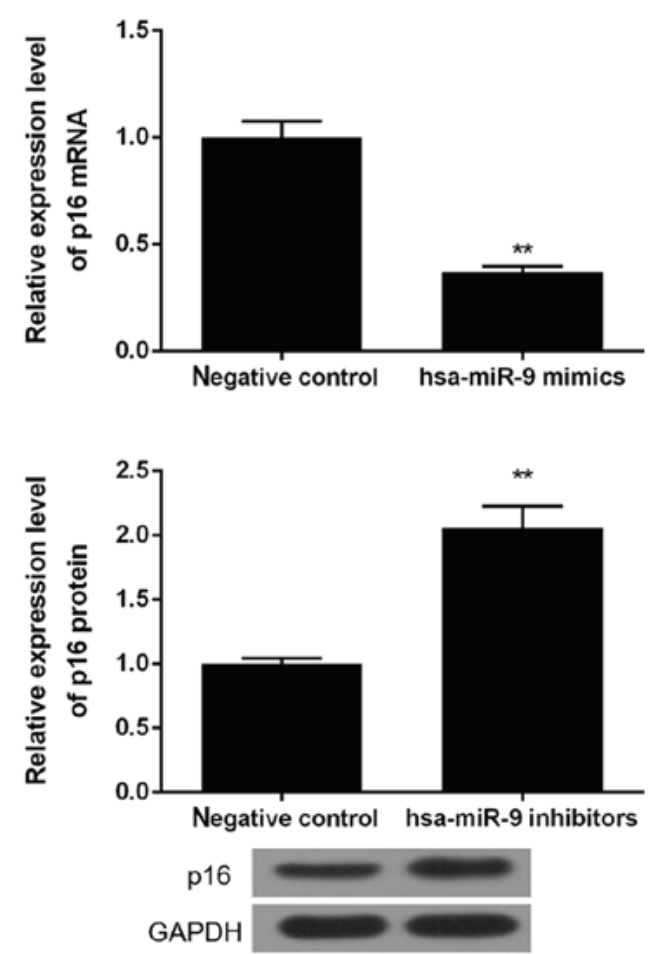

Figure 4. miR-9 depletion increases the expression of p16 in Saos-2 cells. (A) The microRNA.org website was performed to predict the potential target gene for miR-9. Luciferase activity was evaluated using a dual luciferase reporter gene assay kit. ${ }^{* *} \mathrm{P}<0.01$ vs. control + p16-3'-UTR; ${ }^{\# \prime} \mathrm{P}<0.01$ vs. hsa-miR-9 + p16-3'-UTR. (B) The mRNA levels of p16 were determined by RT-qPCR. (C) p16 protein expression was assessed by western blot analysis. *** $<0.01$ vs. negative control.

Silencing of 16 reverses the inhibitoryeffects of miR-9 inhibitor on tumor growth in mice with OS. As shown by the images in Fig. 8A, the tumors in the hsa-miR-9 inhibitors + si-NC group were smaller than those in the hsa-miR-9 inhibitors + si-p16 group. In addition, according to the results of our calculations, as time progressed, the volume of the tumors increased. The tumor volume in the hsa-miR-9 inhibitors + si-p16 group was larger than that in the hsa-miR-9 inhibitors + si-NC group (Fig. 8B). The IHC results also revealed a large number of evident brown particles in the hsa-miR-9 inhibitors + si-NC group (Fig. 8C). Additionally, the tumor weight in the hsa-miR-9 inhibitors + si-p16 group was greater than that in the hsa-miR-9 inhibitors + si-NC group (Fig. 8D).

\section{Discussion}

miRNAs, which are the key regulators of cancer and can regulate the proliferation, migration and invasion of tumor cells, can function both as oncogenes and tumor suppressors. miR-9 has been shown to be highly expressed in lung cancer, hepatocellular carcinoma and OS (35-37) and to be expressed at low levels in ovarian cancer and nasopharyngeal carcinoma $(38,39)$. In this study, we found that the expression of miR-9 in OS tissue was higher than that in adjacent normal tissue. Furthermore, Zhu et al have proven that miR-9 facilitates the growth of OS cells (37). Similar to the findings of this previous study, in this study, we observed that miR-9 mimics increased the proliferation and colony numbers of Saos-2 cells, while miR-9 inhibitors reduced the proliferation and colony numbers of the cells. This phenomenon suggest that miR-9 exerts oncogenic effects on OS.

An uncontrolled cell cycle is the cause of tumor growth and malignant cell proliferation $(40,41)$. Hence, in this study, we examined the role of miR-9 in the cell cycle of Saos- 2 cells. Liu et al demonstrated that miR-9 depletion blocked N2a cells cells at the G1 phase (42). The data from this study revealed that miR-9 mimics arrested the cells in the S phase, and miR-9 inhibitors arrested the cells in the G1 phase. Cyclin A, cyclin D1 and c-Myc expression levels were detected to examine the molecular mechanisms of the cell cycle. The main function of cyclin D1 is to promote cell proliferation. Cyclin D1 combines and activates the cyclin-dependent kinase 4 (CDK4) specific to 


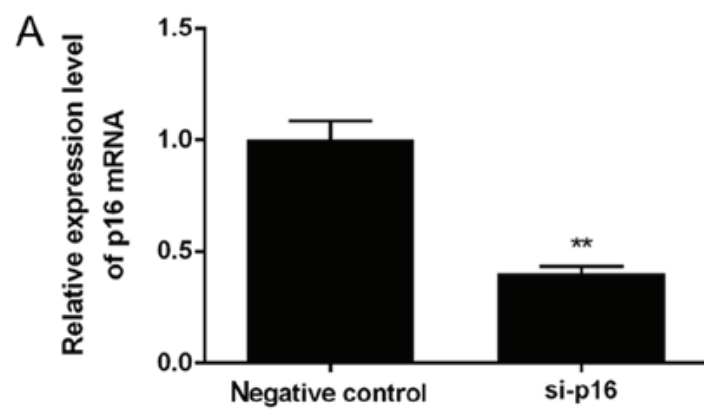

C

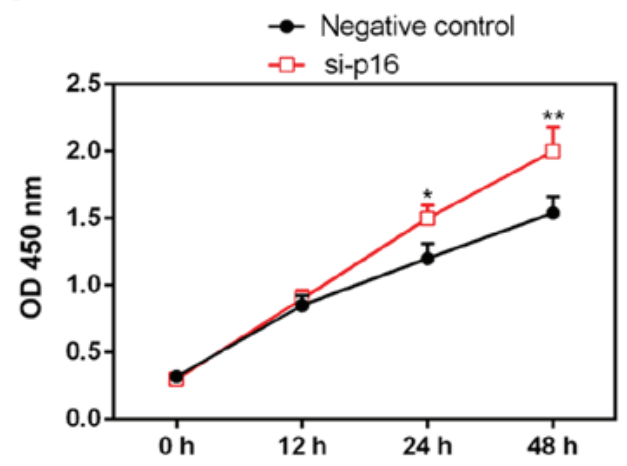

B

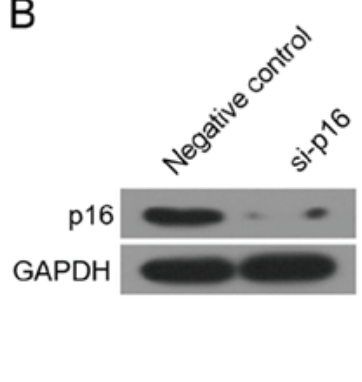

D

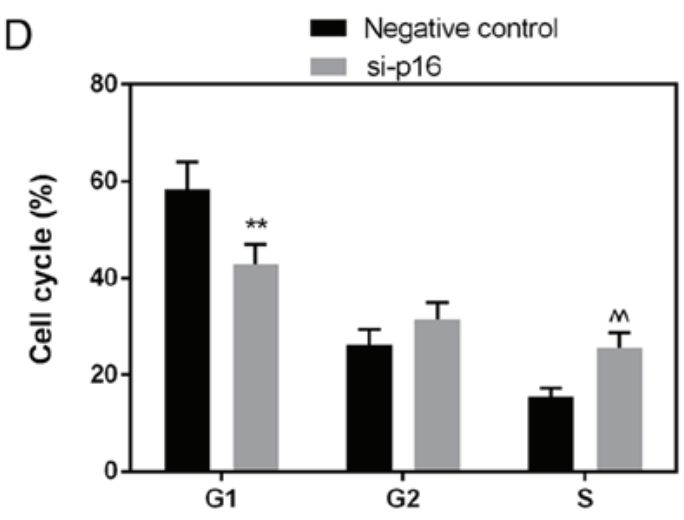

Figure 5. Silencing of p16 enhances the proliferation of Saos-2 cells by promoting cell cycle G1 phase to S phase transformation. Saos-2 cells were subjected to transfection with unspecific scrambled siRNA (negative control) and siRNA p16. (A and B) RT-qPCR and western blot analysis were carried out to analyze p16 expression. (C) The OD value at $450 \mathrm{~nm}$ was read by CCK-8 assay. (D) Cell cycle was investigated by flow cytometry. ${ }^{*} \mathrm{P}<0.05$ and ${ }^{* *} \mathrm{P}<0.01$ vs. negative control; ${ }^{\wedge} \mathrm{P}<0.01$ vs. negative control.

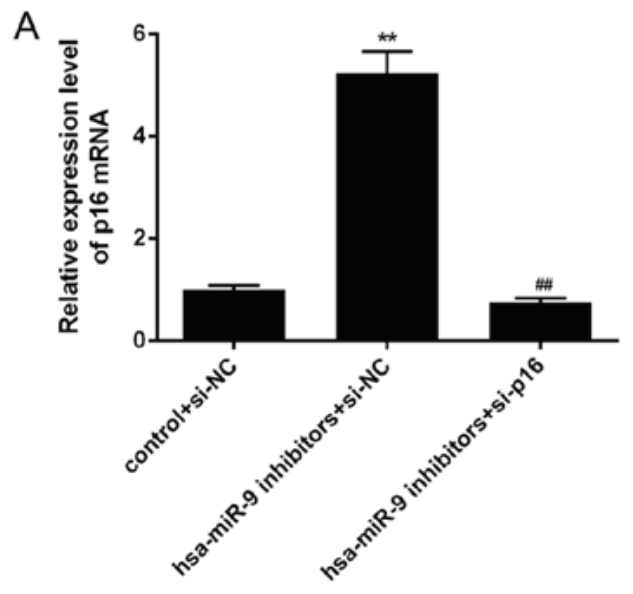

C

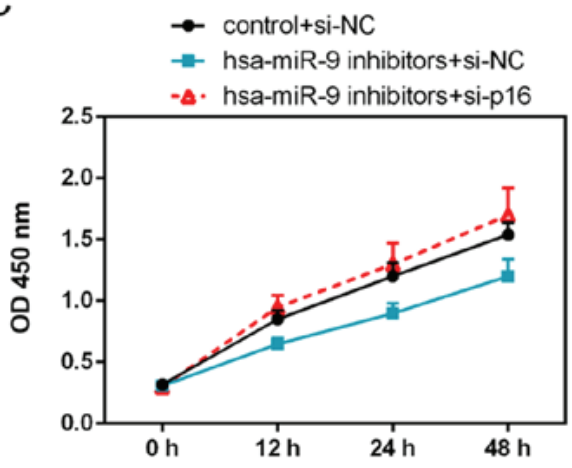

B
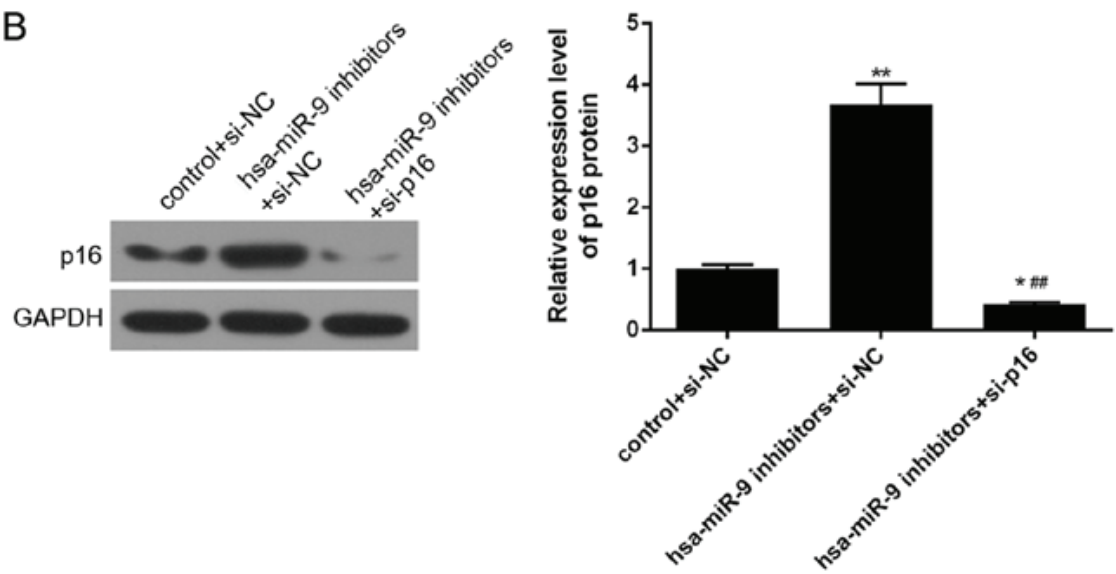

D

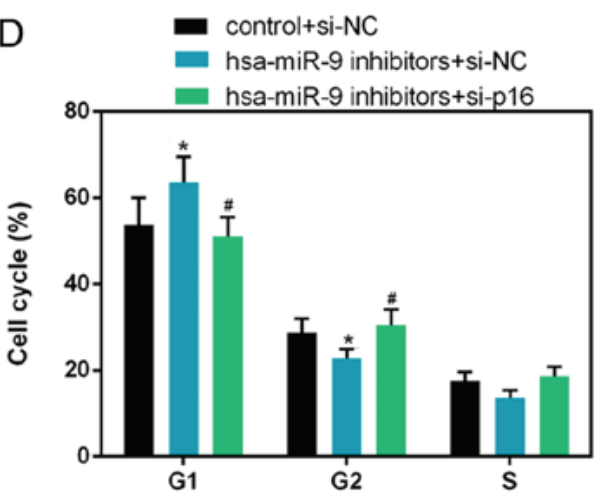

Figure 6. Silencing of p16 reverses the inhibitory effects of miR-9 inhibitor on Saos-2 cell proliferation by promoting cell cycle G1 phase to S phase transformation. (A and B) The mRNA and protein expression levels of p16 were assessed by RT-qPCR and western blot analysis. (C) CCK-8 assay was carried out to determine the OD value. (D) Cell cycle was examined by flow cytometry. ${ }^{*} \mathrm{P}<0.05$ and ${ }^{* *} \mathrm{P}<0.01$ vs. control + si-NC; ${ }^{\#} \mathrm{P}<0.05$ and ${ }^{\# \#} \mathrm{P}<0.01$ vs. hsa-miR-9 inhibitors + si-NC. 

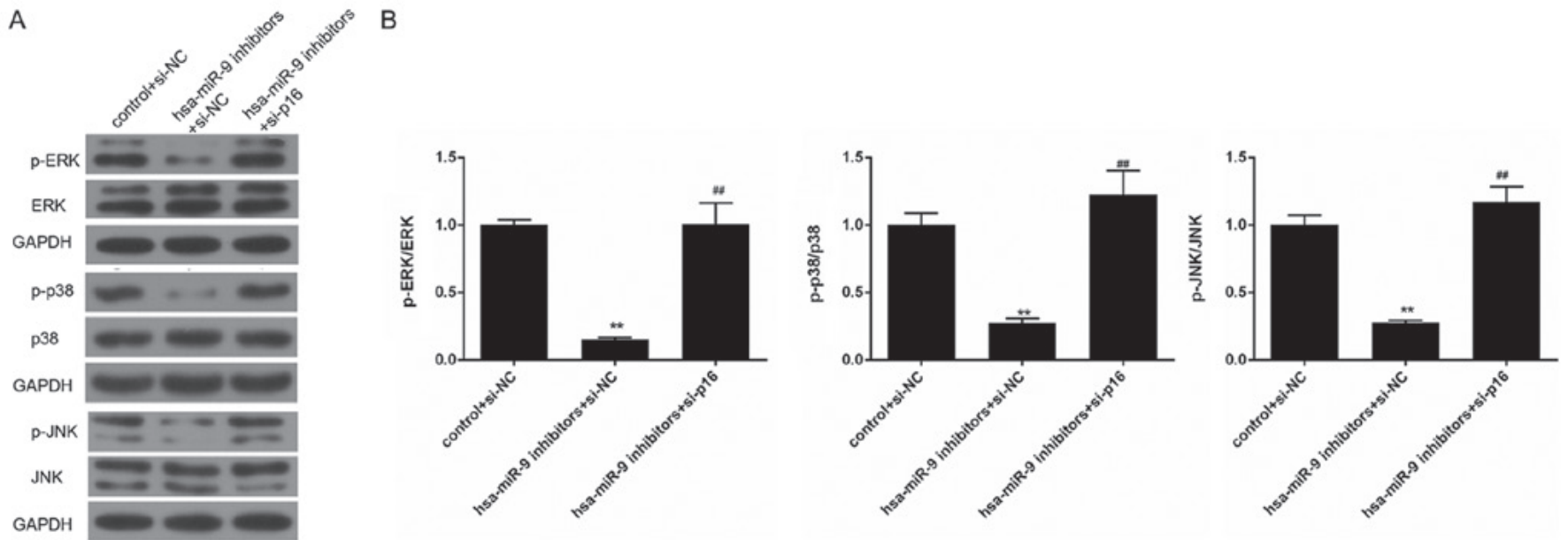

Figure 7. Silencing of p16 reverses the inhibitory effects of miR-9 inhibitor on the ERK/p38/JNK pathway in Saos-2 cells. (A and B) The protein expression levels of ERK, p-ERK, p38, p-p38, JNK and p-JNK were examined by western blot analysis. ${ }^{* * *} \mathrm{P}<0.01$ vs. control + si-NC; ${ }^{* \#} \mathrm{P}<0.01$ vs. hsa-miR-9 inhibitors + si-NC.
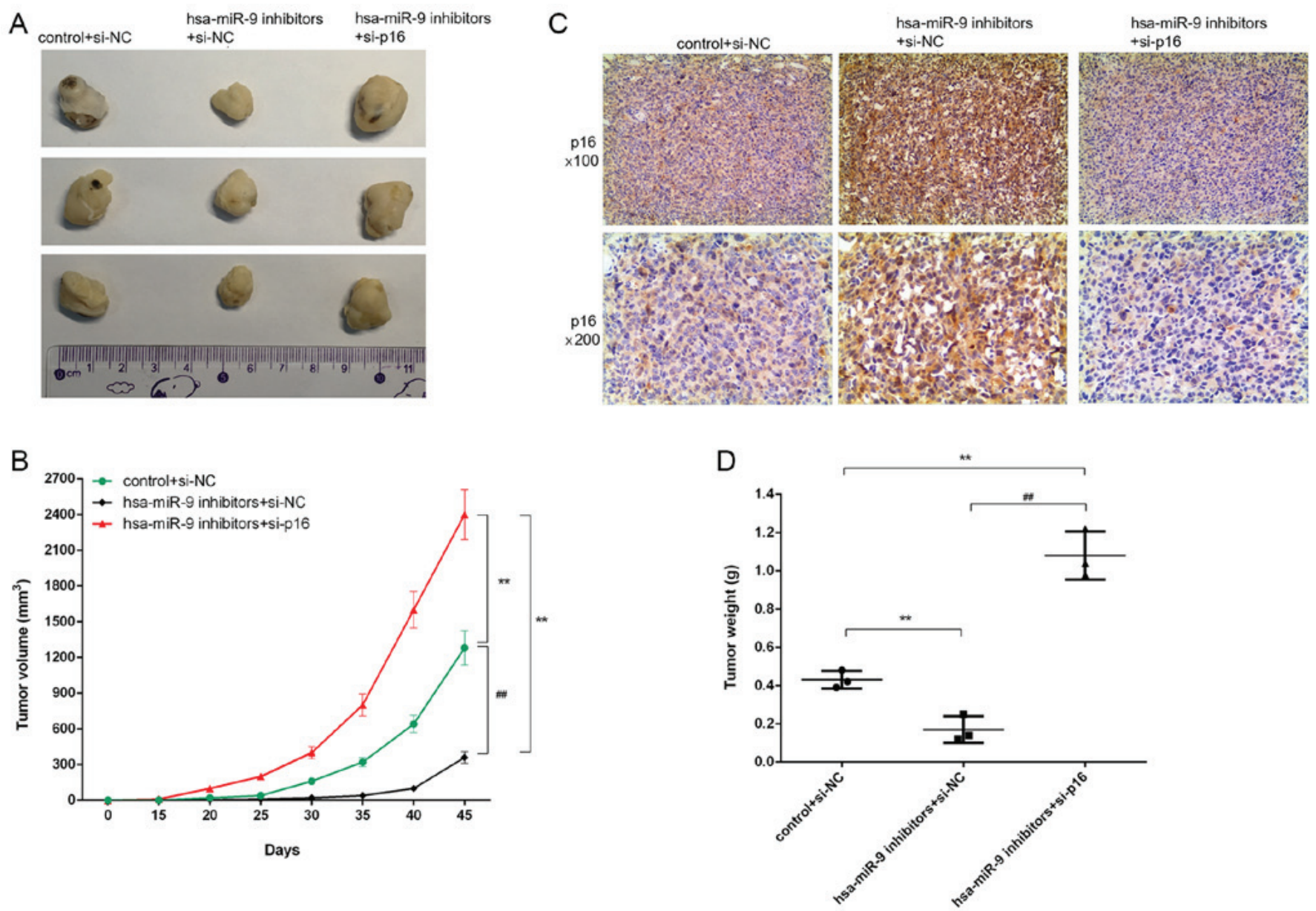

Figure 8. Silencing of p16 reverses the inhibitory effects of miR-9 inhibitor on tumor growth in mice with OS. (A and B) The tumor volume was quantified. (C) p16 expression was assessed by immunohistochemistry. (D) The weight of the tumors was measured. ${ }^{* *} \mathrm{P}<0.01 \mathrm{vs}$. control + si-NC; ${ }^{\# \#} \mathrm{P}<0.01 \mathrm{vs}$. hsa-miR-9 inhibitors + si-NC. OS, osteosarcoma.

the G1 phase, the inhibitor protein $(\mathrm{Rb})$ of which is therefore phosphorylated. The phosphorylated $\mathrm{Rb}$ protein dissociates from its E2F transcription factor, and the E2F transcriptional factor begins to transcribe the gene of the living cell cycle, thereby promoting the cell cycle into the $\mathrm{S}$ phase from the G1 phase (43). Cyclin A mainly activates CDK2 and CDK1 to regulate chromosome replication and mitosis $(44,45)$. The c-Myc gene is an important member of the myc gene family and promotes cell division (46). According to a previous study, miR-9 promotes the growth and cell cycle progression of bladder cancer cells by increasing cyclin D1 expression (47). Zhou et al testified that miR-632 accelerated cell proliferation 
in laryngeal cancer by upregulating cyclin D1 and c-Myc expression (48). The findings of this study demonstrated that miR-9 mimics promoted cyclin A, cyclin D1 and c-Myc expression levels, while miR-9 inhibitors suppressed cyclin A, cyclin D1 and c-Myc expression levels. These results suggest that miR-9 facilitates the proliferation of Saos- 2 cells by arresting the cells in the $\mathrm{S}$ phase, and upregulating cyclin $\mathrm{A}$, cyclin D1 and c-Myc expression levels.

p16 is one of the most common suppressor genes of human tumor cells, encoding a $16 \mathrm{kDa}$ protein, namely the p16 protein (49,50). In 1994, Nobori et al suggested that the role of p16 in cancer suppression was far greater than the role of p53, and its deletion or mutation was associated with the occurrence of a variety of tumors (51). In this study, p16 was found to be expressed at low levels in OS tissue compared to adjacent normal tissue. In addition, p16 is a cyclin dependent inhibitor (CDI), which can negatively regulate the cell cycle by inhibiting CDK $(50,52,53)$. The inactivation of the p16 gene will lead to excessive cell proliferation (54). Thus, we hypothesized that p16 may affect cell proliferation in OS. As expected, we observed that the silencing of p16 significantly promoted the proliferation of Saos-2 cells by arresting the cells in the $\mathrm{S}$ phase.

miRNAs are involved in the progression of various types of cells by regulating their target genes (55-57). O'Loghlen et al demonstrated that the miR-9 family control senescence by mediating p16 gene in cancer (58). Hence, we hypothesized that miR-9 and p16 might have a certain connection in OS. Notably, in this study, according to the microRNA.org website prediction, the 3'-UTR of p16 mRNA had the complementary sites for hsa-miR-9. The luciferase activity was attenuated in the hsa-miR-9 + p16-3'UTR group; however, no change was observed in the hsa-miR-9 + p16-3'UTR mut group. Moreover, miR-9 mimics decreased the expression of p16; however, miR-9 inhibitors increased p16 expression. These data suggest a negative correlation between miR-9 and p16 in OS. Importantly, p16 was found to be a target gene of miR-9 in OS.

To further verify that p16 is a target gene of miR-9 in OS, the growth of Saos-2 cells was measured following transfection with hsa-miR-9 inhibitors and siRNA p16. Furthermore, the effects of miR-9 inhibitor and si-p16 on tumor growth in mice with OS were investigated. The results revealed that the silencing p16 reversed the repression impact of miR-9 on cell growth by arresting G1 phase. In vivo, the data also revealed that p16 depletion reversed the suppressive effects of miR-9 inhibitor on tumor growth. This phenomenon indicated that the carcinogenic effects of miR-9 in OS involve the direct targeting of p16.

Researchers have demonstrated thatERK/p38/JNK pathway involves the regulation of the proliferation, differentiation, apoptosis and metastasis of various cancer cells $(23,24,28,29)$. Wang et al confirmed that miR-155 increases OS cell growth by regulating MAPK signaling (59). Gui et al indicated that miR-497 inhibited the proliferation of OS cells by targeting the MAPK/ERK pathway (60). Zhang et al demonstrated that miR-9 inhibited the growth of hepatocellular carcinoma cells by mediating ERK signaling (61). Ben-Hamo and Efroni proved that miR-9 regulated the p38 pathway in glioblastoma multiforme (62). Herein, we hypothesized that miR-9 may regulate the ERK-p38-JNK pathway in OS. Fortunately, our data revealed that miR-9 inhibitors downregulated the phosphorylation levels of ERK, p38 and JNK. Nevertheless, the silencing of p16 reversed the suppressive effects of miR-9 inhibitor on the ERK/p38/JNK pathway. These results demonstrated that miR-9 depletion downregulates the ERK/p38/JNK pathway by targeting p16.

This study also had some limitations, for example, the number of patients with OS enrolled was not sufficient and the trial period was too short. We thus aim to carry out further studies in the future with a larger sample size in order to validate the results of this study.

In conclusion, the findings of this study demonstrated that miR-9 depletion suppresses cell proliferation by targeting p16 and mediating the activation of the ERK/p38/JNK pathway in OS. These results provide the foundation for future studies on the pathogenesis of OS.

\section{Acknowledgements}

Not applicable.

\section{Funding}

This work study supported by the Medical Science and Technology Research Project of Henan Provincial Health Department (grant no. 201203106).

\section{Availability of data and materials}

The analyzed datasets generated during this study are available from the corresponding author on reasonable request.

\section{Authors' contributions}

SG made substantial contributions to the conception and design of the study. JW, ST and JL contributed to data acquisition, and data analysis and interpretation. SG, ST and JL contributed to the drafting of the article or critically revising it for important intellectual content. All authors agree to be accountable for all aspects of the work in ensuring that questions related to the accuracy or integrity of the work are appropriately investigated and resolved. All authors have read and approved the final manuscript.

\section{Ethics approval and consent to participate}

All procedures performed involving human participants were in accordance with the ethical standards of the institutional and/or national research committee and with the 1964 Helsinki declaration and its later amendments or comparable ethical standards. All patients signed informed consent forms, allowing their tissues to be used in this study. The Ethics Committee of Henan Provincial People's Hospital authorized this research. All animal experiments were performed following the approval of the Henan Provincial People's Hospital Animal Ethics Committee and according to the Guidelines for the Care and Use of Laboratory Animals.

\section{Patient consent for publication}

Not applicable. 


\section{Competing interests}

The authors declare no conflicts of interest.

\section{References}

1. Garcia-Moure M, Martinez-Vélez N, Patiño-García A and Alonso MM: Oncolytic adenoviruses as a therapeutic approach for osteosarcoma: A new hope. J Bone Oncol 9: 41-47, 2016.

2. Misaghi A, Goldin A, Awad M and Kulidjian AA: Osteosarcoma: A comprehensive review. SICOT J 4: 12, 2018.

3. Guenther LM, Rowe RG, Acharya PT, Swenson DW, Meyer SC, Clinton CM, Guo D, Sridharan M, London WB, Grier HE, et al Response Evaluation Criteria in Solid Tumors (RECIST) following neoadjuvant chemotherapy in osteosarcoma. Pediatr Blood Cancer 65: 65, 2018.

4. Huang $\mathrm{Z}$ and Lou C: Application of the alteration uptake ratio of 99mTc-MIBI scintigraphy for evaluating the efficacy of neoadjuvant chemotherapy in osteosarcoma patients. Hell J Nucl Med 21: $55-59,2018$

5. Cavit A, Özcanli H, Sançmis M, Ocak GA and Gürer EI: Tumorous conditions of the hand: A retrospective review of 402 cases. Turk Patoloji Derg 34: 66-72, 2018.

6. Bartel DP: MicroRNAs: Genomics, biogenesis, mechanism, and function. Cell 116: 281-297, 2004.

7. Lee J, Park H, Eom J and Kang SG: MicroRNA-mediated regulation of the development and functions of follicular helper T cells. Immune Netw 18: e7, 2018.

8. Lee RC, Feinbaum RL and Ambros V: The C.elegans heterochronic gene lin-4 encodes small RNAs with antisense complementarity to lin-14. Cell 75: 843-854, 1993.

9. Wightman B, Ha I and Ruvkun G: Posttranscriptional regulation of the heterochronic gene lin-14 by lin- 4 mediates temporal pattern formation in C. elegans. Cell 75: 855-862, 1993.

10. Chen Z, Han Y, Song C, Wei H, Chen Y, Huang K, Li S, Ma D Wang S, Wang J, et al: Systematic review and meta-analysis of the prognostic significance of microRNAs in cervical cancer. Oncotarget 9: 17141-17148, 2017.

11. Hershkovitz-Rokah O, Geva P, Salmon-Divon M, Shpilberg O and Liberman-Aronov S: Network analysis of microRNAs, genes and their regulation in diffuse and follicular B-cell lymphomas. Oncotarget 9: 7928-7941, 2018

12. Ichii $\mathrm{O}$ and Horino T: MicroRNAs associated with the development of kidney diseases in humans and animals. J Toxicol Pathol 31: 23-34, 2018.

13. Iguchi T, Sakurai K, Tamai S and Mori K: Circulating liverspecific microRNAs in cynomolgus monkeys. J Toxicol Pathol 31: 3-13, 2018

14. Wang H, Peng R, Wang J, Qin Z and Xue L: Circulating microRNAs as potential cancer biomarkers: The advantage and disadvantage. Clin Epigenetics 10: 59, 2018.

15. Chen M, Liu YY, Zheng MQ, Wang XL, Gao XH, Chen L and Zhang GM: microRNA-544 promoted human osteosarcoma cell proliferation by downregulating AXIN2 expression. Oncol Lett 15: 7076-7082, 2018

16. Ding J, Sha L, Shen P, Huang M, Cai Q and Li J: MicroRNA-18a inhibits cell growth and induces apoptosis in osteosarcoma by targeting MED27. Int J Oncol 53: 329-338, 2018

17. Tang W, Wang W, Zhao Y and Zhao Z: MicroRNA-874 inhibits cell proliferation and invasion by targeting cyclin-dependent kinase 9 in osteosarcoma. Oncol Lett 15: 7649-7654, 2018.

18. Fenger JM, Roberts RD, Iwenofu OH, Bear MD, Zhang X, Couto JI, Modiano JF, Kisseberth WC and London CA: MiR-9 is overexpressed in spontaneous canine osteosarcoma and promotes a metastatic phenotype including invasion and migration in osteoblasts and osteosarcoma cell lines. BMC Cancer 16: 784, 2016.

19. Jang MH, Kim HJ, Gwak JM, Chung YR and Park SY: Prognostic value of microRNA-9 and microRNA-155 expression in triplenegative breast cancer. Hum Pathol 68: 69-78, 2017.

20. Snezhkina AV, Krasnov GS, Zhikrivetskaya SO, Karpova IY Fedorova MS, Nyushko KM, Belyakov MM, Gnuchev NV, Sidorov DV, Alekseev BY, et al: Overexpression of microRNAs miR-9, -98, and -199 correlates with the downregulation of HK2 expression in colorectal cancer. Mol Biol (Mosk) 52: 220-230, 2018 (In Russian).

21. Wang H, Wu Q, Zhang Y, Zhang HN, Wang YB and Wang W: TGF- $\beta 1$-induced epithelial-mesenchymal transition in lung cancer cells involves upregulation of miR-9 and downregulation of its target, E-cadherin. Cell Mol Biol Lett 22: 22, 2017.
22. Zheng L, Qi T, Yang D, Qi M, Li D, Xiang X, Huang K and Tong Q: microRNA-9 suppresses the proliferation, invasion and metastasis of gastric cancer cells through targeting cyclin D1 and Ets1. PLoS One 8: e55719, 2013.

23. She H, He Y, Zhao Y and Mao Z: Autophagy in inflammation: The p38 $\alpha$ MAPK-ULK1 axis. Macrophage (Houst) 5: e1629, 2018.

24. Tang Q, Tong M, Zheng G, Shen L, Shang P and Liu H: Masquelet's induced membrane promotes the osteogenic differentiation of bone marrow mesenchymal stem cells by activating the Smad and MAPK pathways. Am J Transl Res 10: 1211-1219, 2018.

25. Li S, Ma YM, Zheng PS and Zhang P: GDF15 promotes the proliferation of cervical cancer cells by phosphorylating AKT1 and Erk1/2 through the receptor ErbB2. J Exp Clin Cancer Res 37: $80,2018$.

26. Pinal N, Martín M, Medina I and Morata G: Short-term activation of the Jun N-terminal kinase pathway in apoptosis-deficient cells of Drosophila induces tumorigenesis. Nat Commun 9: 1541, 2018.

27. Yang S, Guo L, Su Y, Wen J, Du J, Li X, Liu Y, Feng J, Xie Y, Bai Y, et al: Nitric oxide balances osteoblast and adipocyte lineage differentiation via the JNK/MAPK signaling pathway in periodontal ligament stem cells. Stem Cell Res Ther 9: 118, 2018

28. Aroui S, Aouey B, Chtourou Y, Meunier AC, Fetoui H and Kenani A: Naringin suppresses cell metastasis and the expression of matrix metalloproteinases (MMP-2 and MMP-9) via the inhibition of ERK-P38-JNK signaling pathway in human glioblastoma. Chem Biol Interact 244: 195-203, 2016.

29. Speth Z, Islam T, Banerjee K and Resat H: EGFR signaling pathways are wired differently in normal 184A1L5 human mammary epithelial and MDA-MB-231 breast cancer cells. J Cell Commun Signal 11: 341-356, 2017.

30. Chen HJ, Lin CM, Lee CY, Shih NC, Peng SF, Tsuzuki M, Amagaya S, Huang WW and Yang JS: Kaempferol suppresses cell metastasis via inhibition of the ERK-p38-JNK and AP-1 signaling pathways in U-2 OS human osteosarcoma cells. Oncol Rep 30: 925-932, 2013.

31. Joo SS and Yoo YM: Melatonin induces apoptotic death in LNCaP cells via p38 and JNK pathways: Therapeutic implications for prostate cancer. J Pineal Res 47: 8-14, 2009.

32. Li T, Zhao J, Ge J, Yang J, Song X, Wang C, Mao J, Zhang Y, Zou Y, Liu Y, et al: Particulate matter facilitates C6 glioma cells activation and the release of inflammatory factors through MAPK and JAK2/STAT3 pathways. Neurochem Res 41: 1969-1981, 2016

33. Livak KJ and Schmittgen TD: Analysis of relative gene expression data using real-time quantitative PCR and the 2(-Delta Delta C(T)) method. Methods 25: 402-408, 2001

34. Faustino-Rocha A, OliveiraPA,Pinho-Oliveira J, Teixeira-Guedes C, Soares-Maia R, da Costa RG, Colaço B, Pires MJ, Colaço J, Ferreira R, et al: Estimation of rat mammary tumor volume using caliper and ultrasonography measurements. Lab Anim (NY) 42: 217-224, 2013

35. Drakaki A, Hatziapostolou M, Polytarchou C, Vorvis C, Poultsides GA, Souglakos J, Georgoulias V and Iliopoulos D: Functional microRNA high throughput screening reveals miR-9 as a central regulator of liver oncogenesis by affecting the PPARA-CDH1 pathway. BMC Cancer 15: 542, 2015.

36. Xu T, Liu X, Han L, Shen H, Liu L and Shu Y: Up-regulation of miR-9 expression as a poor prognostic biomarker in patients with non-small cell lung cancer. Clin Transl Oncol 16: 469-475, 2014.

37. Zhu SW, Li JP, Ma XL, Ma JX, Yang Y, Chen Y and Liu W: miR-9 modulates osteosarcoma cell growth by targeting the GCIP tumor suppressor. Asian Pac J Cancer Prev 16: 4509-4513, 2015.

38. Laios A, O'Toole S, Flavin R, Martin C, Kelly L, Ring M, Finn SP, Barrett C, Loda M, Gleeson N, et al: Potential role of miR-9 and miR-223 in recurrent ovarian cancer. Mol Cancer 7: 35, 2008.

39. Lu J, Xu X, Liu X, Peng Y, Zhang B, Wang L, Luo H, Peng X, Li G, Tian W, et al: Predictive value of miR-9 as a potential biomarker for nasopharyngeal carcinoma metastasis. Br J Cancer 110: 392-398, 2014.

40. Jia GQ, Zhang MM, Wang K, Zhao GP, Pang MH and Chen ZY: Long non-coding RNA PlncRNA-1 promotes cell proliferation and hepatic metastasis in colorectal cancer. J Cell Biochem 119: 7091-7104, 2018

41. Zhou Q, You C, Zheng C, Gu Y, Gu H, Zhang R, Wu H and Sun B: 3-Nitroacridine derivatives arrest cell cycle at G0/G1 phase and induce apoptosis in human breast cancer cells may act as DNA-target anticancer agents. Life Sci 206: 1-9, 2018. 
42. Liu W, Liu C, Yin B and Peng XZ: Functions of miR-9 and miR-9* during aging in SAMP8 mice and their possible mechanisms. Zhongguo Yi Xue Ke Xue Yuan Xue Bao 37: 253-258, 2015.

43. Di Sante G, Di Rocco A, Pupo C, Casimiro MC and Pestell RG: Hormone-induced DNA damage response and repair mediated by cyclin D1 in breast and prostate cancer. Oncotarget 8: 81803-81812, 2017.

44. Li Y, Zhang J, Gao W, Zhang L, Pan Y, Zhang S and Wang Y: Insights on structural characteristics and ligand binding mechanisms of CDK2. Int J Mol Sci 16: 9314-9340, 2015.

45. Roskoski R Jr: Cyclin-dependent protein kinase inhibitors including palbociclib as anticancer drugs. Pharmacol Res 107: 249-275, 2016.

46. Goetzman ES and Prochownik EV: The role for Myc in coordinating glycolysis, oxidative phosphorylation, glutaminolysis, and fatty acid metabolism in normal and neoplastic tissues. Front Endocrinol (Lausanne) 9: 129, 2018.

47. Wang H, Zhang W, Zuo Y, Ding M, Ke C, Yan R, Zhan H, Liu J and Wang J: miR-9 promotes cell proliferation and inhibits apoptosis by targeting LASS2 in bladder cancer. Tumour Biol 36 9631-9640, 2015.

48. Zhou ZX, Zhang ZP, Tao ZZ and Tan TZ: MiR-632 promotes laryngeal carcinoma cell proliferation, migration and invasion through negative regulation of GSK33. Oncol Res: Mar 21, 2018 (Epub ahead of print). doi: 10.3727/096504018X15213142076069.

49. Lee JK, Lee KH, Kim SA, Kweon SS, Cho SH, Shim HJ, Bae WK, Chung IJ, Chung WK, Yoon TM, et al: p16 as a prognostic factor for the response to induction chemotherapy in advanced hypopharyngeal squamous cell carcinoma. Oncol Lett 15: 6571-6577, 2018 .

50. Ottria L, Candotto V, Cura F, Baggi L, Arcuri C, Nardone M, Gaudio RM, Gatto R, Spadari F and Carinci F: HPV acting on E-cadherin, p53 and p16: Literature review. J Biol Regul Homeost Agents 32 (Suppl 1): 73-79, 2018

51. Nobori T, Miura K, Wu DJ, Lois A, Takabayashi K and Carson DA: Deletions of the cyclin-dependent kinase-4 inhibitor gene in multiple human cancers. Nature 368: 753-756, 1994.

52. Hirama T and Koeffler HP: Role of the cyclin-dependent kinase inhibitors in the development of cancer. Blood 86: 841-854, 1995.
53. Serrano M, Hannon GJ and Beach D: A new regulatory motif in cell-cycle control causing specific inhibition of cyclin D/CDK4. Nature 366: 704-707, 1993.

54. Pu X, Zhu L, Fu Y, Fan Z, Zheng J, Zhang B, Yang J, Guan W, Wu H, Ye Q, et al: Companied P16 genetic and protein status together providing useful information on the clinical outcome of urinary bladder cancer. Medicine (Baltimore) 97: e0353, 2018.

55. Goody D and Pfeifer A: MicroRNAs in brown and beige fat Biochim Biophys Acta Mol Cell Biol Lipids 1864: 29-36, 2018.

56. Guo J and Cheng Y: MicroRNA-1247 inhibits lipopolysaccharides-induced acute pneumonia in A549 cells via targeting CC chemokine ligand 16. Biomed Pharmacother 104: 60-68, 2018.

57. Song Z, Cooper DKC, Cai Z and Mou L: Expression and Regulation profile of mature MicroRNA in the pig: Relevance to xenotransplantation. BioMed Res Int 2018: 2983908, 2018.

58. O'Loghlen A, Brookes S, Martin N, Rapisarda V, Peters G and Gil J: CBX7 and miR-9 are part of an autoregulatory loop controlling p16(INK) (4a). Aging Cell 14: 1113-1121, 2015.

59. Wang C, Zhang X, Zhang C, Zhai F, Li Y and Huang Z: MicroRNA-155 targets MAP3K10 and regulates osteosarcoma cell growth. Pathol Res Pract 213: 389-393, 2017.

60. Gui ZL, Wu TL, Zhao GC, Lin ZX and Xu HG: MicroRNA-497 suppress osteosarcoma by targeting MAPK/Erk pathway. Bratisl Lek Listy 118: 449-452, 2017.

61. Zhang J, Cheng J, Zeng Z, Wang Y, Li X, Xie Q, Jia J, Yan Y, Guo Z, Gao J, et al: Comprehensive profiling of novel microRNA-9 targets and a tumor suppressor role of microRNA-9 via targeting IGF2BP1 in hepatocellular carcinoma. Oncotarget 6: 42040-42052, 2015.

62. Ben-Hamo R and Efroni S: Correction: Gene expression and network-based analysis reveals a novel role for hsa-miR-9 and drug control over the p38 network in glioblastoma multiforme progression. Genome Med 4: 87, 2012.

c) (i) $\Theta$ This work is licensed under a Creative Commons Attribution-NonCommercial-NoDerivatives 4.0 International (CC BY-NC-ND 4.0) License. 